\title{
Emilio entre nosotros
}

El 14 de junio de 2019 este Departamento (Traducción e Interpretación, Universidad de Málaga) sufrió un golpe del que no nos hemos recuperado: la noticia de la partida de Emilio, el Profesor Ortega Arjonilla. Dejábamos de tener entre nosotros a alguien que irradiaba con intensidad en múltiples direcciones. En Emilio he encontrado una y otra vez, durante más de dos décadas, a una persona de cercana humanidad, a un amigo seguro, a un compañero generoso, a un intelectual comprometido, a un investigador de amplios horizontes, a un profesor fecundo, a un gestor bienhumorado, a un trabajador de energía incomprensible, a un maestro eficaz. Personalmente podría dar testimonio de haber encontrado en Emilio apoyo real y duradero en días oscuros y sé que otros han tenido experiencias similares. Pero prefiero recordar su amable bonhomía de cualquier mañana cuando me lo encontraba por los pasillos y, sobre todo, poner de manifiesto cómo la influencia positiva de su personalidad, de sus logros, de su dedicación no ha mermado con su marcha. Su impacto sigue siendo perceptible entre sus colaboradores, entre sus discípulos, entre quienes lo tratamos y le estaremos siempre agradecidos, en su obra escrita y en los efectos de su dedicación a la traducción, la lengua francesa y la investigación concebida como esfuerzo totalizador y humanista. Hemos perdido a Emilio, pero sigue entre nosotros.

Emilio, el Profesor Ortega Arjonilla, no solo ha dejado huella en nuestro Departamento. Sus esfuerzos y tareas han sido igualmente fecundos fuera de Málaga y de España. Son muchos los docentes, investigadores, traductores a quienes podríamos haber pedido, con plenas garantías, que escribiesen unas palabras acerca de nuestro añorado compañero. Se lo hemos solicitado al Profesor Pedro San Ginés, una autoridad en estas materias y persona muy cercana a Emilio.

Salvador Peña Martín 